Res Publica Revista de Historia de las Ideas Políticas

ISSN: $1131-558 \mathrm{X}$

https://dx.doi.org/10.5209/rpub.79249

Acceleration theory, temporal regimes, and politics today.

\title{
An interview with Hartmut Rosa
}

Felipe Torres $^{1}$; Hartmut Rosa ${ }^{2}$

Hartmut Rosa is currently one of the best-known sociologists in Germany. In this interview, we undertake a brief retrospective of his initial work on temporality. In doing so, we evaluate his theory 15 years after its first publication in German (Suhrkamp 2005). The interview seeks to examine the topicality of the acceleration theory through the voice of one of its main authors, having in mind current socio-political phenomena such as the pandemic deceleration, social discontents (both global and local), energy challenges, and the revival of old nationalisms.

Felipe Torres (FT): Last year (2020) your major book Social Acceleration ${ }^{3}$ turned 15 years old. It seems a fair time to evaluate some of its main theses. Since its appearance in German in 2005 and its translation into English (2013), it has marked a groundbreaking contribution to acceleration studies in particular, and social theory more generally. As an introductory question, and a more personal one as well, I would like to first ask you about your impressions on the success of this book. How have you received the impact of your book? Was it something that took you by surprise or did you expect that this success might occur?

Hartmut Rosa (HR): Well, on the one hand, of course I was surprised by all the attention and interest the book got. It started in Germany with a long positive review by the prestigious "Wochenzeitung" [weekly newspaper] Die Zeit, and then, about two years later, it drew even more attention in France, when Le Monde made it the title of its magazine. After that, Brazil and then the Spanish- and English-speaking worlds followed, and now it is also popular in Japan, China and Korea, and even in Iran and the Arab-speaking countries. Of course, I did not foresee or expect this in the least; I was a virtually unknown sociologist in 2005! But on the other hand, when I was working on Social Acceleration, I did notice that it was a topic that had been neglected in the social sciences, although it was a really pressing social issue. I realized that in all areas of social life -in schools and universities, media and politics, the economy and the arts- the need for speed and time scarcity were huge and increasing problems. So, it did not take me totally by surprise to see that there was a lot of social interest in the topic.

FT: In the last decades, and particularly since the COVID pandemic, we have witnessed contradictory trends in the description and normativity of the acceleration/deceleration theses. From a descriptive point of view, we can count the global economic deceleration and the current pandemic crisis; on the other hand, increasing automation speeds up production while digital media links people all over the world in even faster ways than previous analogic technology. In normative terms, many socio-political claims (bio-food, post-growth) began to defeat the acceleration process, while others actually called to maintain $i t^{4}$ or even to increase the acceleration of society ${ }^{5}$. In your view, what are those aspects of the acceleration thesis that are still present today since your book was published? For instance, is incessant growth an uncontested claim today? Hence, what are those phenomena that you perceive as weaker, about to disappear, or no longer present for the acceleration theory today?

HR: In my view, the core thesis of the acceleration book is not that acceleration is a normative demand, but rather, that it is a structural requirement of modern, capitalist societies. And I do not see any change in this situation since 2005. Of course, people are demanding bio-technologies, they are dreaming of a slow life, and growth as a social goal is politically and normatively contested. But the fact is: we still need to achieve growth, acceleration, and innovation year by year, as individuals as well as collectives, in

\footnotetext{
Instituto de Sociología, Pontificia Universidad Católica de Chile. Observatorio de Transformaciones Socioeconómicas (ANID/PCI/Max Planck Institute for the Study of Societies/MPG190012).

E-mail: ftorren@uc.cl.

Institute of Sociology, Friedrich-Schiller-Universität Jena / Max Weber Center for Advanced Cultural and Social Studies, Erfurt University (Germany).

E-mail: hartmut.rosa@uni-jena.de.

H. Rosa, Social Acceleration. A New Theory of Modernity, Columbia University Press, 2013. Originally published in German as Beschleunigung. Die Veränderung der Zeitstrukturen in der Moderne, Frankfurt, Suhrkamp, 2005.

S. Lash, Critique of Information, London, Sage, 2002

A. Williams and N. Srnicek, \# Accelerate: Manifesto for an Accelerationist Politics, reprinted in R. Mackay and A. Avenassian (eds.), \# Accelerate: The Accelerationist Reader, Falmouth, Urbanomic, 2014 [2013], pp. 349-362.
} 
order to maintain the institutional status quo. I call this in the books published after Social Acceleration a mode of dynamic stabilization. And this is what I think is highly problematic: it leads to a burning up of the atmosphere and to a burning out of individuals. The idea advocated by the Accelerationists, that we simply need to develop faster technologies, to speed up our pace of life and let ourselves be liberated by the forces and powers of change, progress and development, is in fact a very old idea -we find it in the futurist writings of Marinetti and, to some extent, even in the communist manifesto, and we fall to it in everyday life when we think: well, let's have faster, better, high-tech equipment in order to overcome our time-scarcity. It never works. It is a complete illusion. The faster we get, the more aggravated the problem becomes. This is what I, following Paul Virilio, call "frenetic standstill" (polar inertia) ${ }^{6}$, and, once again, it has structural reasons, it is not a cultural or normative thing: modern, capitalist societies can only reproduce their structure and their institutional status quo by speeding up and growing without any end in sight. For us mortals this means: we need to run faster and faster each year just to stay in place, whether we love speed, like the accelerationists, or condemn it, like the decelerationists. This was true in 2005 and it is true in 2022, it will only change when we re-invent our whole form of life, our mode of existence.

FT: In recent years, several phenomena related to acceleration started to gain attention within the scholarship. Notorious works applied your acceleration theory in different fields, sometimes as a theoretical framework and sometimes from a critical point of view. Among them we can include the link between speed and politics ${ }^{7}$, the accelerated cultural flows ${ }^{8}$, the reception of acceleration in Science and Technology Studies ${ }^{9}$, or even the acceleration process within academia ${ }^{10}$. Your Jena colleague Klaus Dörre $^{11}$ has remarked upon the extremely uneven distribution of social rhythms, while Filip Vostal has pointed out the deflationary acceleration character ${ }^{12}$. This blooming panorama leads not only to reckoning that acceleration can be studied in several fields, but also to the question of whether there is "one" or rather "multiple" accelerations. Actually, as you know, I tried to shed some light on these multiple temporal expressions in my Temporal Regimes book ${ }^{13}$. In this context, do you think that a theoretical response is necessary? Are there different acceleration processes in India and Latin America in tune with the diverse forms of modernity? How we can explain theoreti- cally the multiple expressions of acceleration without rejecting its modern character?

HR: Well, obviously, in your book you have really done a great and remarkable job at pointing out and explaining the plurality, heterogeneity and multiplicity of temporal regimes we can find in the modern world, particularly in a global context. I certainly do not want to dispute this. Nevertheless, I insist on two things which to my mind are absolutely crucial if we want to understand the nature and working of modern society -society in the singular. Number one: Yes, of course the temporal patterns, structures, horizons and expectations are quite different in China, India, Japan, Brazil, Chile, South Africa or Europe. So of course, you can observe a lot of differences that stem from diverging histories and cultural traditions. But what makes all of these contemporary societies modern is that they are running in a mode of dynamic stabilization. This, in my view, is the defining characteristics of modernity: A society can be called modern when its mode of stabilization is $d y$ namic, i.e., when it systematically requires growth, acceleration and innovation in order to reproduce its structure and to maintain its institutional status quo. Growth, by the way, is just one form of acceleration because it means that more is produced, distributed and consumed over a given period of time -however that "more" is defined. Now, dynamic stabilization means that without acceleration, the economy is in trouble, you lose jobs, companies close down, etc. But more than this: by consequence, the health care system (if there is one), the educational system, the pension schemes, the cultural institutions: they all will run into an institutional crisis when the motor of growth/acceleration stalls, and in the end, the political system will be delegitimated, too. This is why all of the countries mentioned above strive for economic growth, technological acceleration, higher rates of innovation, etc. And this is why we uniformly observe an increased shortage of time, rising rates of burnout and problems of cultural, psychological and ecological desynchronization in China as in India, Chile, Brazil or South Africa. There is a structural connection between modernization and acceleration and therefore a (unitary) temporal logic that we should not debate away by insisting on the diversity of temporal regimes. The abstract, singular logic of acceleration takes on many different "substantial" forms and consequences in different cultural contexts for, of course, the social and cultural contexts continue to be different. But the logic of dynamic stabilization is what defines modernity everywhere. Thus, we have multiple modernities in "substantive" terms (a wide

P. Virilio, Polar Inertia, London, SAGE Publications, 1999.

S. Glezos, Speed and Micropolitics: Bodies, Minds, and Perceptions in an Accelerating World, London and New York, Routledge, 2020.

S. Sharma, In the Meantime: Temporality and Cultural Politics, Durham, Duke University Press, 2014.

J. Wajcman, Pressed for Time. The Acceleration of Life in Digital Capitalism, Chicago, The Chicago University Press, 2015.

F. Vostal, Accelerating Academia: The Changing Structure of Academic Time, London, Palgrave, 2016.

K. Dörre, "Die Corona-Pandemie - eine Katastrophe mit Sprengkraft", Berliner Journal für Soziologie 30 (2) 2020, pp. 165-190.

F. Vostal, "Social Acceleration: Five «Deflationary» Comments", Res Publica 24 (3), 2021.

F. Torres, Temporal Regimes: Materiality, Politics, Technology, London and New York, Routledge, 2021. 
variety of temporal regimes and socio-cultural practices), but a coherent, "unitary" power of temporal change driving social transformation.

And number two: If we talk of the diversity and multiplicity of temporal regimes and practical temporalities -and again, I certainly do not want to deny them- we are tempted to think of acceleration and deceleration as two equivalent temporal processes or tendencies: while some processes speed up, others slow down. And if we contemplate our social environments, this obviously seems to be true: there are many things that slow down, for example, traffic in a traffic jam, or bureaucratic decision procedures, or $\mathrm{UN}$ action to regulate financial markets, etc. But the most important point of my theory of acceleration, in fact, the point I really wanted to make in my 2005 book, is the point that there is no equilibrium between these two forces (acceleration and deceleration), that there is a clear asymmetry between them, and that it is this cultural, structural, and temporal asymmetry that really defines modernity. The argument goes like this: while processes of acceleration are systematically driven and powered by three external motors capitalism, functional differentiation and the cultural move to answer the human fear of death with the attempt to speed up and thus increase our "quantum" of life- there is no equivalent "counter-force", or "counter motor". Things that slowdown in our societies are either residual, i.e., they are under pressure to speed up, or they are (unintended) side-effects of dynamization, like the traffic jam, or they are reactions to speed-up processes, like movements for slow-food or slow cities or slow science, etc. Sometimes they are even functional or instrumental for the acceleration process. For example, a lot of people in the middle classes now try to temporarily slow down with the help of "mindfulness" and yoga practices in order to be more efficient and successful in their accelerated lives. In all of these cases, deceleration is derivative or secondary to the logic of speed. Put differently: there is no equivalent to the logic and temporal force of dynamic stabilization.

FT: The last point leads me to the next question. In many places we are facing a social malaise with global inequalities, institutional politics and even deep cultural transformations mirrored by feminist, environmental and anti-racist movements. With different goals and intensities, all of them seek to trigger deep social changes. And they want these changes now (i.e., Time's Up, Fridays for Future). In this sense, the claim for speeding-up social change is a common normative factor in collective action. Far from defeating your thesis on acceleration as the structural temporal modern regime, in my opinion the current global conflicts lead us to reconsider the emancipatory potentials of acceleration. For instance, in Chile there was a referendum to replace the constitution imposed by the Pinochet dictatorship one year after the social uprising of October 2019, something that was impossible for democratic sectors to achieve in 30 years. In this regard, do you think that collective action can be considered as another acceleration motor? How should we locate collective action worldwide (climate change, gender equality, Black Lives Matter) as a contingent or structural motor for speeding-up social changes? More precisely, is conflict a structural or contingent driving force of acceleration processes?

HR: In order to answer this question, it is once again important to see what acceleration theory really is about: it does not say that speed-up is necessarily wrong, bad or capitalist, or anything of that sort. This is why I have always insisted, passionately insisted, that I am NOT a proponent of slow-down or deceleration. Slowness certainly is not a value in itself. A fast ambulance is better than a slow one, a fast internet connection is always preferable to a slow one, and a slow rollercoaster is not just boring but in fact dangerous - it could fall down from the loops. And this is why I speak of post-growth, not of degrowth: in a context where there is hunger and starvation, we of course need a growth in agricultural production. But it is perverse if the food industry is structurally forced to grow in a context where obesity is the problem. The point of acceleration theory is to identify the "empty" logic of acceleration as a structural requirement. That year by year we need to speed up without going anywhere, just to avoid socioeconomic disaster: this is the problem I identified, and this is what I criticize. Now, social movements which are directed either against this capitalist and structurally institutionalized logic -against the logic of dynamic stabilization-per se, or which attempt to alleviate the pernicious side-effects of this system (like the environmentalists), are not part of the "acceleratory machine". It would be great if they could speed up their actions. Thus, we need to see that there are two forms of conflict: struggle against the logic of the modern social formation, against the mode of dynamic stabilization on the one hand, and conflict within its logic, for example, the fight for higher wages, on the other hand. While the former could be identified as "contingent" forces of social change, the latter are actually structurally included in the system.

FT: As said above, the COVID-19 pandemic has changed many things. You have written about this global phenomenon in several works ${ }^{14}$. Scholarship all over the world has stressed the big challenge for

\footnotetext{
H. Rosa, "Corona: Entschleunigung durch die Pandemie", Apotheken Umschau, (24/03/2020), 2020a https://www.apotheken-umschau.de/Coronavirus/Corona-Entschleunigung-durch-die-Pandemie-557669.html. Accessed November 2021; H. Rosa, "Das Virus ist der radikalste Entschleuniger unserer Zeit", Der Tagesspiegel, (24/03/2020), 2020b, https://www.tagesspiegel.de/politik/soziologe-hartmut-rosa-ueber-covid-19-das-virus-istder-radikalste-entschleuniger-unserer-zeit/25672128.html Accessed 3 March 2021; and H. Rosa, "Pfadabhängigkeit, Bifurkationspunkte und die Rolle der Wissenschaft: Ein soziologischer Deutungsversuch der Corona-Krise”, Berliner Journal für Soziologie 30 (2), 2020, pp. $191-213$.
} 
an accelerated social life that the pandemic represents (mobility, production, services). Do you think we are facing a new "Slow-down Era"? In other words, will the forced slow-down stabilize itself as a structural societal condition (a permanently decelerated society) or rather as an exceptional-contingent situation? I am aware that this question might sound like "futurology", but I am pretty sure many people would like to know your opinion and forecast on this topic given the current condition worldwide.

HR: There can be no doubt that the pandemic has had a deceleratory effect that is actually unique in modern history. For the first time since the $18^{\text {th }}$ century, social life has slowed down on a global scale. 95\% of air traffic, for example, was reduced for some time, up to $50 \%$ of traffic on the highways was as well, and so was movement in inner cities. Furthermore, social activities from sports events to schools and universities were halted. We can actually physically measure this deceleration by the massive decrease in $\mathrm{CO} 2$ emissions, and even from seismological observations which prove that the human-caused material-physical movement has diminished during times of lockdown: the planet literally reduced its vibrations. But there are three things we need to keep in mind here. Firstly, we can clearly see here that deceleration in my usage is a descriptive, not a normative concept. A lot of people suffered from this deceleration -for example when they lost their jobs. And furthermore, the slow-down was unevenly distributed across societies: while some middle-class people could happily stay at home, others, for example hospital workers, experienced even more stress. Secondly, while there was a reduction in physical and material movement and speed, there was a corresponding acceleration in our digital lives. This is a trend that has been going on for some time, but it was greatly magnified by the pandemic: for many, the situation really approached the form Virilio had in mind when he predicted the end-state of a "polar inertia". He predicted a world in which bodies would no longer move at all -they would remain completely motionless, wired to digital streams of data and information. I am a good example for this: while the radius of my physical motion for quite some time was more or less restricted to my apartment, and most of the day to my computer, I was digitally rushing from conferences in India to meetings in Delhi and discussions with colleagues from Chile and so on. This is the physical manifestation of a frenetic standstill. Quite an unpleasant and unhealthy state of affairs. But thirdly, this clearly shows that the pandemic per se has not changed any of the structural conditions of modern society, or, put differently: it has left the logic of dynamic stabilization untouched. Of course, you can slow down a modern society, but only at the cost of its institutions getting in crises. This is what we have now. Let us see what will come next. After all, moments of crises are precisely the historical points where social change is possible. Here, it is remarkable to realize that it was not the virus itself that halted the soccer leagues and grounded the airplanes: it was political action. Maybe we as a society can learn from this and use the power of collective political action to really change the system.

FT: Let me again connect your book on Acceleration with a more current context: we have witnessed the rising of right-wing nationalisms that, in many regards, are a response to the changing values espoused by capitalist globalization, as well as a claim to stop the incessant movement in modern societies, instead favoring a more stable identity. According to Aleida Assmann ${ }^{15}$, we live in an accelerated globalization which is another way to name the preponderance of time over space and the global over the local. In this scenario, do you think it is possible to consider the nationalistic wave as a conservative response and claim against the "situational identity"? Is the global nationalist wave a rabid response to what you coined in Social Acceleration ${ }^{16}$ as the suggestive "situational identity" thesis? To put it in other words: is the incessant movement of social acceleration an indirect justification for current "pro-static", national-grounded or local-based, traditional identities?

HR: Yes, I clearly do see a connection here. There is a strong yearning in many people for stability in their lives, for reliability and for connection. They do feel like isolated, uprooted, powerless atoms in a relentless global torrent, and against this, they ache for strong national or religious identities. Manuel Castells has very insightfully written on this. In my analysis, what lies behind these nationalistic and populistic movements is a growing sense of alienation: people feel powerless, disconnected from politics, their voices being muted. But then, there is a double-fallacy in the response they give to this situation: first, they attribute their alienation to the aliens, the foreigners, the non-locals, and turn nationalistic or racist. They fail to see that the real cause for their alienation is no other, unprivileged people, but a systemic logic that forces them to become ultra-flexible, to take on situational identities. And secondly, they seek the wrong solution: they demand determined and resolute political action, they actually seek accelerated political action against everything that troubles them, and hence, they ask for a strong political leader who defines the national identity and ensures the realization of the national interest. But this will not remove their alienation; in the end, it will increase it. For the real problem, which I have tried to identify in my studies on the political crisis, lies in what can be called "democratic desynchronization". Democracy, which could and should be the modern way of struggling

\footnotetext{
15 A. Assmann, Ist die Zeit aus den Fugen? Aufstieg und Fall des Zeitregimes der Moderne, München, Carl Hanser Verlag, 2013.

16 H. Rosa, Social Acceleration, op. cit., chapter 11: "Situational Identity: Of Drifters and Players", pp. $224-250$.
} 
for a political identity, is inevitably time-consuming. Democracy is not just about taking a vote, it is about formulating and deliberating together about the right course of action -and this process of deliberation can bring about something like a republican national identity. But in late-modernity, the markets and the media, technological innovations and cultural shifts have become too fast for this process to be properly enacted -hence, democracy has become too slow. We will certainly not solve this problem by electing populist leaders.

FT: Finally, as with the first question, I would like to finish with a more personal, prospective, query. Many temporal studies scholars ask ourselves if Hartmut Rosa will one day return to write on temporalities. You have been quite prolific writing on other relevant issues (i.e., Resonance ${ }^{17}$ and Uncontrollabil$i t y^{18}$ ) and we know you are working on other projects now related to property and social energy. But the hope remains: will Hartmut Rosa surprise us again in the foreseeable future with another temporal work? Is there room for that?

HR: Well, look, actually what I have been doing all along, through all my writings, has been an attempt to understand the nature of modern society, to understand our current predicament. I am driven by the desire to understand who we are, how we have come here and where we could go from here as social beings, as modern societies. I guess I have taken this way of asking from Charles Taylor, who was my strongest source of intellectual inspiration as a student. I have written my dissertation thesis on his work, and there, I thought what I need to do is to understand the "modern identity". The idea of a late-modern "situational identity" actually originated from there. Then, I shifted a bit and realized that temporality is of crucial importance if we are to un- derstand modern society and our place in it. There is an inherent tension between the notion of "identity", which resists the transforming forces of time, and the logics of dynamization and acceleration. So, the book on social acceleration in a way was a response to my first book on identity: modern society and modern lives need to be understood by their persistent trend towards change and transformation. Then I was surprised by the reception the book earned: suddenly, I was called the guru or the prophet of deceleration. This confused me, because, as I have said, I never thought that speed per se is bad and slowness is good. So, I started to think about alienation: speed is bad when it leads to alienation. But then I asked myself: what is a non-alienated state of affairs? And my answer to this question was not identity, but resonance. The interesting thing about the notion of resonance is that it is something dynamic, processual, even fleeting and temporary - but it nevertheless bestows a sense of belonging and connection. So, resonance is my current solution to the problem of modernity; it replaced the "static" idea of identity, but I certainly will move on from here. What I want to say is this: it was not a predominant interest in time or temporality that drove me to my work on social acceleration, but an interest in modernity, in understanding the driving forces of our society. But now, in 2021, I do actually feel a certain need to come back to the analysis of the temporal nature of our lives. For I have strangely neglected the temporal aspects and dimensions of resonance. So, quite recently, I have started to think about resonance and alienation as two different modes of experiencing time, of being in time. Hence, it might well be that I return to time very soon. I simply do not know yet.

FT: Many thanks for your willingness and time professor.

17 H. Rosa, Resonance: A Sociology of Our Relationship to the World, Cambridge, Polity, 2019.

18 H. Rosa, The Uncontrollability of the World, Cambridge, Polity, 2020. 